\title{
PENGARUH BAURAN PEMASARAN TERHADAP KEPUASAN PELANGGAN UNTUK MENINGKATKAN NIAT PEMBELIAN ULANG (Studi Pada Oli Sepada Motor Merek Eni di Kota Denpasar)
}

\author{
Andy Tejantara ${ }^{1}$ \\ Tjok Gde Raka Sukawati \\ ${ }^{1,2}$ Fakultas Ekonomi dan Bisnis Universitas Udayana (Unud), Bali, Indonesia \\ e-mail : andytejantara@ymail.com
}

\begin{abstract}
ABSTRAK
Penelitian ini bertujuan untuk mengetahui pengaruh bauran pemasaran terhadap kepuasan pelanggan untuk meningkatkan niat pembelian ulang. Penelitian dilakukan di Kota Denpasar dengan jumlah sample yang diambil sebanyak 120 orang. Metode yang digunakan non probability sampling. Data dikumpulkan dengan metode survei yaitu menyebarkan kuisioner kepada responden. Teknik analisis data yang digunakan adalah PLS (Partial Least Square). Berdasarkan hasil analisis ditemukan bahwa (bauran pemasaran) kualitas produk, persepsi harga, saluran distribusi dan daya tarik promosi berpengaruh positif dan signifikan terhadap kepuasan pelanggan. Hal ini menunjukan bahwa semakin baik kualitas produk, persepsi harga, saluran distribusi dan daya tarik promosi akan menciptakan kepuasan pelanggan. Pelanggan yang merasa puas terhadap suatu produk akan menciptakan niat pembelian ulang. Perusahaan dapat menciptakan niat pembelian ulang terhadap produknya melalui peningkatan kepuasan pelanggan.
\end{abstract}

Kata kunci: bauran pemasaran, kepuasan pelanggan, niat pembelian ulang

\begin{abstract}
This study aims to determine the effect of marketing mix to customer satisfaction to improve repurchase intention. The study was conducted in Denpasar City with the number of samples taken as many as 120 people. The method used is non probability sampling. Data were collected by survey method which distributed questioner to respondent. Data analysis technique used is PLS (Partial Least Square). Based on the analysis results found that (marketing mix) product quality, price perception, distribution channel and promotion appeal positively and significantly influence to customer satisfaction. This shows that the better the quality of the product, the perception of the price, the distribution channels and the attractiveness of the promotion will create customer satisfaction. Customers who are satisfied with a product will create repurchase intentions. Companies can create repurchase intentions for their products through increased customer satisfaction.
\end{abstract}

Keywords: marketing mix, customer satisfaction, repurchase intention 


\section{PENDAHULUAN}

Oli merupakan salah satu komponen penting dalam sepeda motor, selain oli berperan sebagai pelumas mesin untuk mencegah terjadinya gesekan dan benturan, oli mesin juga sebagai pendingin ruang mesin. Pentingnya peranan oli menyebabkan konsumen harus berhati-hati dalam memilih produk oli sepada motor. Belakangan ini banyak terjadi kasus "turun mesin" yang dikarenakan keterlambatan konsumen dalam mengganti oli mesin. Keterlambatan penggantian oli disebabkan karena terlalu cairnya oli mesin yang digunakan, sehingga membuat konsumen tidak mengetahui bahwa oli mesin tersebut harus diganti lebih cepat. Penggantian oli mesin secara rutin merupakan hal yang harus dilakukan, akan tetapi jika penggantian oli mesin yang dilakukan dengan periode waktu yang singkat akan menyebabkan biaya yang dikeluarkan oleh konsumen menjadi lebih besar dan konsumen menjadi tidak puas akan produk oli mesin tersebut. Permasalahan tersebut menyebabkan perusahaan oli sepeda motor asing maupun lokal berlomba-lomba memproduksi oli berkualitas. Konsumen tidak hanya menginginkan produk yang berkualitas, namun juga produk yang relatif murah dan mudah untuk didapatkan.

Salah satu perusahaan yang memproduksi oli sepeda motor adalah PT. ALP Petro Industri. Perusahaan ini merupakan perusahaan swasta internasional yang berlokasi di Italy. Produk yang diproduksi oleh PT. ALP Petro Industri adalah oli Eni. Oli Eni dulunya dikenal dengan nama oli Agip. Oli Agip merupakan oli yang sangat diminati dan dikenal di Indonesia, akan tetapi semakin banyaknya pesaing yang masuk dalam pasar oli mesin sepeda motor di Indonesia menyebabkan 
penjualan dari oli Agip menurun. Menurut Tribun Otomotif penjualan oli Agip terbesar pada tahun 2006. Tahun 2007 penjualan oli Agip mulai menurun seiring dengan munculnya produk-produk baru dari pesaingnya, dan terus mengalami penurunan pada tahun-tahun berikutnya. Tahun 2016 oli Agip mulai bangkit kembali dengan produk barunya dan bergganti nama menjadi oli Eni. Oli Eni pada tahun 2017 masuk dalam 8 besar penjualan oli sepeda motor terbaik di Indonesia. (Tribunnews.com).

Tabel 1.

Hasil Studi Pendahuluan Pengguna Oli Sepeda Motor di Kota Denpasar

\begin{tabular}{clc}
\hline No. & \multicolumn{1}{c}{ Merek } & Pengguna (Orang) \\
\hline 1. & Pertamina & 14 \\
2. & AHM & 12 \\
3. & Top One & 10 \\
4. & Eni & 10 \\
5. & Federal & 8 \\
6. & Castrol & 3 \\
7. & Evalube & 2 \\
8. & Motul & 1 \\
Sumber $:$ Data diolah, 2018
\end{tabular}

Tabel 1 hasil studi pendahuluan survei kuesioner memperlihatkan oli sepeda motor yang paling banyak digunakan oleh masyarakat Kota Denpasar. Berdasarkan hasil studi pendahuluan terlihat bahwa pengguna produk oli sepeda motor merek Eni sebanyak 10 orang dari 60 responden, atau sebesar 17\%. Data tersebut menunjukan oli Eni mampu bersaing di pasar oli sepeda motor yang sangat ketat. Persaingan yang ketat menuntut PT. ALP Petro Industri untuk terus berinovasi demi mempertahankan pelanggan. Pelanggan merupakan alasan sebuah perusahaan dapat bertahan dan berkembang. Alasan ini membuat pelanggan menjadi tujuan utama bagi perusahaan. Perusahaan dapat bertahan apabila mampu mempertahankan pelanggannya dalam artian membuat pelanggan mau membeli kembali produk yang dijual atau disebut dengan menciptakan niat pembelian 
ulang (repurchase intention) terhadap produk oli sepeda motor merek Eni. (Kotler dan Keller, 2012:150) berpendapat bahwa "setelah konsumen membeli produk tersebut, konsumen bisa puas atau tidak puas dan terlibat dalam perilaku pasca pembelian. Pelanggan yang puas akan kembali membeli produk, akan tetapi pelanggan yang merasa tidak puas akan mencoba produk lain yang diproduksi perusahaan yang berbeda".

Kepuasan memiliki peran penting dalam menciptakan niat pembelian ulang, dimana menurut Kotler kepuasan (satisfaction) adalah perasaan senang atau kecewa seseorang yang muncul setelah membandingkan kinerja (hasil) produk yang dipikirkan terhadap kinerja (atau hasil) yang diharapkan. Jika kinerja berada di bawah harapan maka pelanggan tidak puas. Jika kinerja memenuhi harapan maka pelanggan puas. Jika kinerja melebihi harapan maka pelanggan amat puas atau senang (Kotler, 2006:177). Jadi, kepuasan ini merupakan kesan bagi pelanggan terhadap suatu produk atau jasa. Semakin tinggi kinerja atau kualitas produk dari harapan maka konsumen akan puas dan sebaliknya jika kinerja dibawah harapan maka konsumen tidak puas.

Perusahaan terus berusaha untuk meningkatkan kepuasan pelanggan agar pelanggan mau membeli kembali produk tersebut terus menerus, salah satu strategi pemasaran yang dapat dilakukan perusahaan untuk meningkatkan kepuasan konsumen dan niat pembelian ulang adalah bauran pemasaran (marketing mix). Bauran pemasaran (marketing mix) adalah seperangkat alat pemasaran yang digunakan perusahaan untuk terus menerus mencapai tujuan pemasarannya di pasar sasaran (Kotler dan Keller, 2012:119). Konsumen yang 
mendapatkan produk yang sesuai harapan atau keinginkan tentu akan menjadi puas terhadap produk tersebut, sehingga bauran pemasaran ini berperan besar dalam meningkatkan kepuasan pelanggan. Bauran pemasaran (marketing mix) di dalamnya terdapat beberapa elemen marketing dengan unsur 4P, yaitu: product, price, place, promotion. Produk (product) adalah barang atau jasa yang akan diterima seorang pembeli ketika mereka mengeluarkan sejumlah uang. Barang atau jasa tersebut yang kita jual biasanya bukan hanya sekedar menjual produk, tetapi juga kualitas pelayananya. Inilah yang bisa menjadi daya tarik tersendiri bagi kita yang menawarkan nilai tambah. Harga (price) adalah jumlah uang yang dibutuhkan untuk mendapatkan suatu barang beserta pelayanannya. Setelah produk yang diproduksi siap untuk dipasarkan, maka perusahaan akan menentukan harga dari produk tersebut. Distribusi (place) adalah kegiatan atau fungsi untuk memindahkan produk disertai dengan hak pemiliknya dari produsen ke konsumen akhir atau pemakai. Promosi (promotion) adalah strategi dalam mengkomunikasikan informasi produk atau jasa dari penjual kepada pembeli.

Bauran pemasaran (marketing mix) merupakan strategi pemasaran yang banyak digunakan oleh perusahaan. Perusahaan yang menggunakan strategi ini harus benar-benar dalam mengelola bauran pemasaran agar kinerja perusahaan dapat optimal. Tujuan utama dari strategi ini adalah untuk menciptakan kepuasan pelanggan sehingga dapat meningkatkan niat pembelian ulang. Hal ini juga diperkuat dengan hasil penelitian yang dilakukan oleh Mevita (2013) hasil peneliatin tersebut menjelaskan bahwa produk, harga, distribusi dan promosi berpengaruh positif dan siginifikan terhadap kepuasan pelanggan. Hasil penelitian 
Palma (2016) menemukan bahwa kualitas produk berpengaruh signifikan terhapdap kepuasaan pelanggan dan kepuasan pelanggan berpengaruh signifikan terhadap niat beli ulang. Variabel kualitas produk tidak berpengaruh signifikan terhadap niat beli ulang.

Berdasarkan latar belakang masalah yang telah dipaparkan, maka tujuan dari penelitian ini adalah untuk menjelaskan pengaruh kualitas produk, persepsi harga, saluran distribusi, dan daya tarik promosi terhadap kepuasan pelanggan oli sepeda motor merek Eni. Untuk menjelaskan pengaruh kepuasan pelanggan terhadap niat pembelian ulang oli sepeda motor merek Eni. Penelitian ini diharapkan akan memberikan manfaat teoritis berupa dapat menambah refrensi yang digunakan untuk penelitian lebih lanjut, khususnya penelitian tentang bauran pemasaran kepuasan pelanggan dan niat pembelian ulang. Manfaat praktis berupa dapat memberikan masukan dan pertimbangan bagi perusahaan, ataupun reseller untuk menetapkan strategi yang tepat dibidang pemasaran, serta dapat memberikan informasi mengenai peran bauran pemasaran dalam mempengaruhi kepuasan dan niat pembelian ulang pelanggan oli Eni di Kota Denpasar.

Bauran pemasaran adalah perangkat alat pemasaran yang digunakan perusahaan untuk mengejar tujuan perusahaannya. Maka, dapat disimpulkan bahwa bauran pemasaran merupakan satu perangkat yang terdiri dari produk, harga, promosi dan distribusi, yang didalamnya akan menentukan tingkat keberhasilan pemasaran dan semua itu ditujukan untuk mendapatkan respon yang diinginkan dari pasar sasaran. (Kotler dan Keller, 2012:119). 
Produk (Product) adalah segala sesuatu yang dapat ditawarkan kepada pasar agar menarik perhatian, akuisisi, penggunaan, atau konsumsi yang dapat memuaskan suatu keinginan atau kebutuhan (Kotler dan Amstrong, 2014:248). Saat ini semua produsen memahami begitu pentingnya peranan dan arti kualitas produk yang unggul untuk memenuhi harapan pelanggan pada semua aspek produk yang dijual ke pasar. Para petinggi dan manajemen puncak perusahaan juga umumya semakin menyadari dan mempercayai adanya keterhubungan langsung antara kualitas produk terhadap customer satisfaction (kepuasan pelanggan) yang pada akhirnya akan meningkatkan raihan pangsa pasar (market share) di pasar sasaran.

Harga (price) adalah sejumlah uang yang harus dibayar oleh pelanggan untuk memperoleh produk (Kotler dan Amstrong, 2014:73). Variabel ini merupakan hal yang dapat dikendalikan dan menentukan diterima atau tidaknya suatu produk oleh pelanggan. Harga semata-mata tergantung pada kebijakan perusahaan tetapi tentu saja dengan mempertimbangkan berbagai hal. Murah atau mahalnya harga suatu produk sangat relatif sifatnya. Oleh karena itu, perlu dibandingkan terlebih dahulu dengan harga produk serupa yang diproduksi atau dijual oleh perusahaan lain.

Saluran distribusi (place) adalah struktur unit organisasi antar perusahaan dan agen serta penyalur, penjual grosir dan eceran diluar perusahaan yang melaluinya sebuah komoditi, produk atau jasa dipasarkan (Yudhi Koesworodjati, 2006:306). 
Promosi (promotion) merupakan salah satu variable dalam bauran pemasaran yang sangat penting dilaksankan oleh perusahaan dalam memasarkan produk atau jasa. Promosi adalah semua kegiatan yang dimaksudkan untuk menyampaikan atau mengkomunikasikan suatu produk kepada pasar sasaran, , untuk memberi informasi tentang keistimewaan, kegunaan dan yang paling penting adalah tentang keberadaanya, untuk mengubah sikap ataupun untuk mendorong orang untuk bertindak dalam membeli suatu produk (Rambat Lupiyoadi, 2013:178).

Penelitian oleh Alelign (2014), Ehsani (2014), Palma (2016), Atiyah (2016), Jahanshahi (2011), Dudin (2017), Sukanto (2015), dan Veva (2015) menemukan bahwa kualitas produk berpengaruh positif dan signfikan terhadap kepuasan pelanggan. Berdasarkan kajian empiris tersebut maka hipotesis penelitian dirumuskan sebagai berikut,

$\mathrm{H}_{1}$ : Kualitas produk berpengaruh positif dan signifikan terhadap kepuasan pelanggan

Penelitian oleh Sukanto (2015), Ehsani (2014), dan Ahmed (2015) menemukan bahwa persepsi harga memiliki pengaruh positif dan signifikan terhadap kepuasan pelanggan. Berdasarkan kajian empiris tersebut maka hipotesis penelitian dirumuskan sebagai berikut,

$\mathrm{H}_{2}$ : Persepsi harga berpengaruh positif dan signifikan terhadap kepuasan pelanggan

Penelitian oleh Sukanto (2015), Gultom (2014), Rao (2014), dan Amilia (2016) menemukan bahwa saluran distribusi memiliki pengaruh positif dan 
signifikan terhadp kepuasan pelanggan. Berdasarkan kajian empiris tersebut maka hipotesis penelitian dirumuskan sebagai berikut,

$\mathrm{H}_{3}$ : Saluran distribusi berpengaruh positif dan signifikan terhadap kepuasan pelanggan

Penelitian oleh Faradina (2016), Dharmayoga (2017), Ginantra (2017), Mevita (2013), Jama (2013), dan Sukanto (2015) menemukan bahwa promosi berpengaruh positif terhadap kepuasan pelanggan. Berdasarkan kajian empiris tersebut maka hipotesis penelitian dirumuskan sebagai berikut :

$\mathrm{H}_{4}$ : Daya tarik pormosi berpengaruh positif dan signifikan terhadap kepuasan pelanggan

Penelitian oleh Noviar (2015), Varga (2014), Yulisetiarini (2017) dan Dharmayoga (2017) menemukan bahwa terdapat pengaruh positif dan signifikan kepuasan pelanggan terhadap niat pembelian ulang. Berdasarkan kajian empiris tersebut maka hipotesis penelitian dirumuskan sebagai berikut,

$\mathrm{H}_{5}$ : Kepuasan pelanggan berpengaruh positif dan signifikan terhadap niat pembelian ulang

Berdasarkan kajian pustaka yang telah diuraikan dan hasil penelitian terhadahulu, maka kerangka konseptual yang dapat dirumuskan dalam penelitian ini adalah sebagai berikut, 


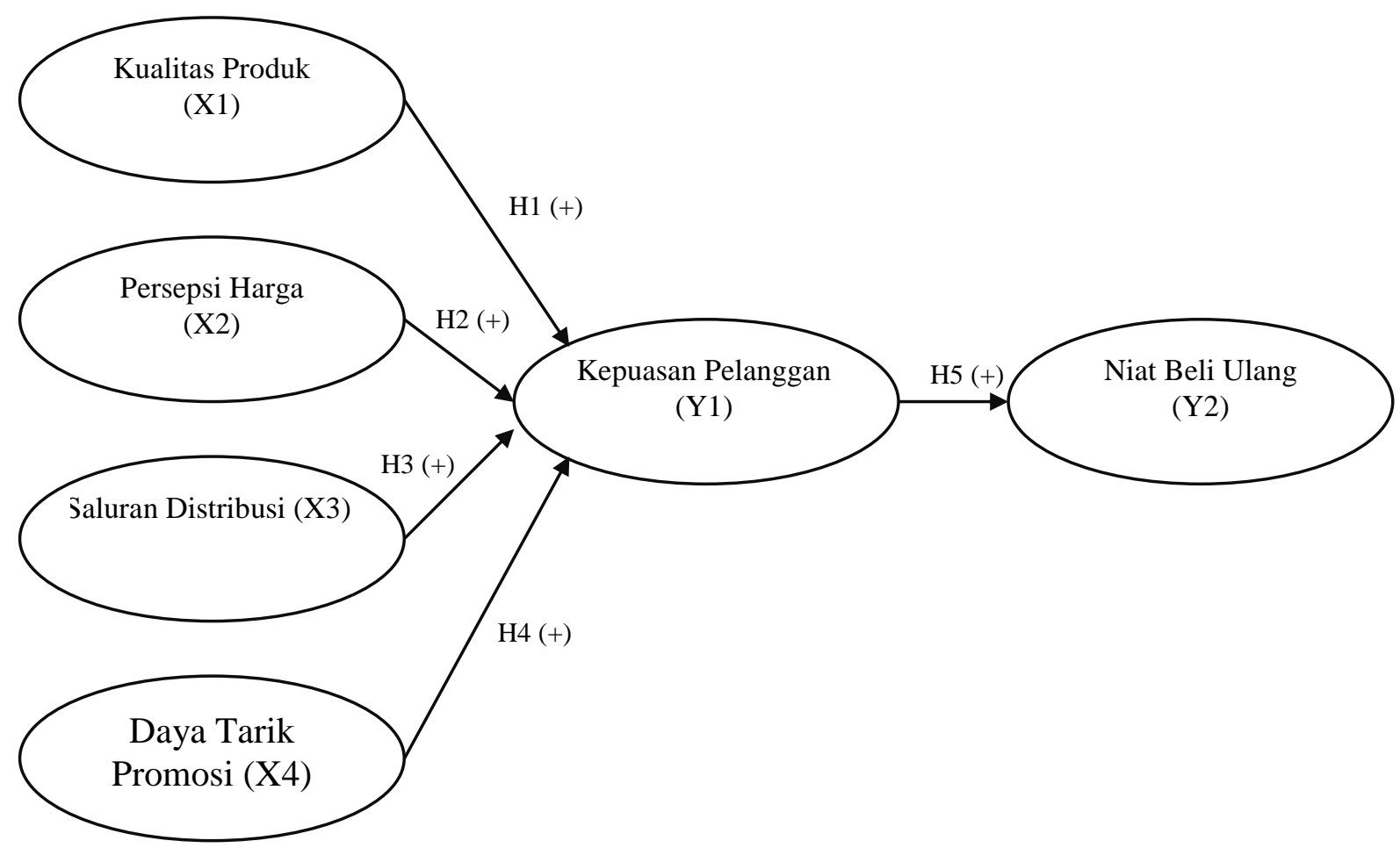

\section{Gambar 1. Kerangka Konseptual}

\section{METODE PENELITIAN}

Penelitian ini menurut tingkat ekplanasinya menggunakan metode asosiatif yang bersifat kausal (sebab akibat) yang bertujuan untuk mengetahui pengaruh variabel bauran pemasaran terhadap kepuasan dan niat pembelian ulang konsumen oli mesin sepeda motor merek Eni di Kota Denpasar. Penelitian ini akan dilakukan di Kota Denpasar. Kota ini dipilih karena menurut Badan Pusat Stratistik (BPS), Kota Denpasar memiliki tingkat pengguna transportasi sepeda motor terbesar di antara kabupaten yang ada di Provinsi Bali. Hal ini didukung dengan banyak adanya bengkel sepeda motor di Kota Denpasar khususnya yang menjual oli Eni. 
Andy Tejantara, Pengaruh Bauran Pemasaran terhadap...

Objek dalam penelitian ini merupakan perilaku konsumen pengguna oli sepeda motor merek Eni. yang ingin diukur niat pembelian ulang khususnya mengenai hubungan antara pengaruh bauran pemasara, kepuasan konsumen dan niat pembelian ulang. Variabel-variabel yang akan dianalisis dalam penelitian ini yaitu variabel independen berupa kualitas produk $\left(\mathrm{X}_{1}\right)$, persepsi harga $\left(\mathrm{X}_{2}\right)$, saluran distribusi $\left(\mathrm{X}_{3}\right)$ dan daya tarik promosi $\left(\mathrm{X}_{4}\right)$. Variabel intervening berupa kepuasan pelanggan $\left(\mathrm{Y}_{1}\right)$ dan variabel dependen berupa niat pembelian ulang $\left(\mathrm{Y}_{2}\right)$. Dalam mengukur ke enam variabel tersebut, digunakan beberapa indikator yang disajikan dalam Tabel 2 sebagai berikut,

Tabel 2.

Indikator Penelitian

\begin{tabular}{|c|c|c|c|}
\hline No. & Variabel & Indikator & Sumber \\
\hline 1. & $\begin{array}{l}\text { Kualitas } \\
\text { produk }\end{array}$ & $\begin{array}{ll}\text { 1. } & \text { Kemasan produk } \\
\text { 2. } & \text { Ketahanan produk } \\
\text { 3. } & \text { Keandalan produk }\end{array}$ & Tjiptono (2012) \\
\hline 2. & $\begin{array}{l}\text { Persepsi } \\
\text { harga }\end{array}$ & $\begin{array}{l}\text { 1. Harga yang sesuai kualitas } \\
\text { 2. Harga yang terjangkau } \\
\text { 3. Harga bersaing dengan produk lain }\end{array}$ & $\begin{array}{l}\text { Nugraheni dan } \\
\text { Ferdinan (2013) }\end{array}$ \\
\hline 3. & $\begin{array}{c}\text { Saluran } \\
\text { distribusi }\end{array}$ & $\begin{array}{l}\text { 1. Kemudahan untuk memperoleh produk } \\
\text { 2. Ketersediaan produk } \\
\text { 3. Lokasi pembelian produk }\end{array}$ & Oktavita (2013) \\
\hline 4. & $\begin{array}{c}\text { Daya tarik } \\
\text { promosi }\end{array}$ & $\begin{array}{l}\text { 1. Ketepatan media promosi } \\
\text { 2. Iklan yang menarik } \\
\text { 3. Pesan dalam iklan mudah dimengerti }\end{array}$ & Oktavita (2013) \\
\hline 5. & $\begin{array}{l}\text { Kepuasan } \\
\text { pelanggan }\end{array}$ & $\begin{array}{ll}\text { 1. } & \text { Senang mengukana produk } \\
\text { 2. Harapan yang terpenuhi } \\
3 & \text { Merasa ouas }\end{array}$ & Pratiwi (2012) \\
\hline 6. & $\begin{array}{l}\text { Niat } \\
\text { pembelian } \\
\text { ulang }\end{array}$ & $\begin{array}{l}\text { 1. Melakukan pembelian kembali } \\
\text { 2. Relationship dengan produk berlangsung lama } \\
\text { 3. Tetap kembali membeli produk meski harga naik }\end{array}$ & Prastiwi (2012 \\
\hline
\end{tabular}

Populasi dari penelitian ini adalah seluruh warga Kota Denpasar yang pernah menggunakan oli Eni dalam kurun waktu November 2017 - Januari 2018 yang tidak diketahui jumlahnya dengan pasti. Penelitian ini mengambil sampel dengan teknik non probability sampling. Teknik pemilihan sampel menggunakan teknik purposive sampling, yaitu teknik penentuan sampel berdasarkan 
pertimbangan maupun syarat-syarat tertentu. Adapun pertimbangan yang digunakan dalam pengambilan sampel adalah sebagai berikut, Pelanggan yang telah melakukan pembelian produk Oli Eni untuk keperluan pribadi minimal sebanyak 2 kali selama minimal tiga bulan terakhir, Jenjang pendidikan minimal SMA. Dengan asumsi bahwa responden dengan tingkat pendidikan minimal SMA dapat memahami dan mampu menjawab kuesioner secara objektif, dan berdomisili di Kota Denpasar

Dalam penelitian menggunakan multivariate dalam melakukan analisis, maka jumlah anggota sampel minimal 5 sampai 10 kali dari jumlah variabel yang akan diteliti (Sugiyono, 2016:95). Jika formula ini digunakan maka ukuran sampel berada pada rentang 90 sampai dengan 180 responden. Mengingat keterbatasan sumber daya digunakan Jadi, responden yang dibutuhkan dalam melakukan penelitian ini adalah sebanyak 120 responden.

Data dikumpulkan dengan metode survei yaitu menyebarkan kuisioner kepada responden. Penyebaran kuesioner dilakukan secara langsung dan disebar dengan memanfaatkan media internet. Kuisioner diberikan secara langsung dengan bertatap muka serta mengirimkan ke alamat email atau media internet yang digunakan responden.

Jenis data yang digunakan dalam penelitan ini adalah jenis data yang dikelompokkan menurut sifatnya, yaitu data kualitatif dan data kuantitatif. Data kualitatif berupa pendapat dari responden mengenai pernyataan yang tertera di dalam kuisioner. Data kuantitatif berupa usia responden, tingkat penggunaan masyarakat Denpasar. Sumber data yang digunakan dalam penelitian ini adalah 
sumber data primer dan sekunder. Sumber primer adalah responden yang memberikan tanggapan dalam. Sumber sekunder adalah pihak lain yang mempublikasikan data yang dikutip terkait dengan topik penelitian ini, seperti; Badan Pusat Statistik (BPS), tribun news, dan specta.

Jenis instrumen yang digunakan berupa angket atau kuesioner dengan pemberian skor menggunakan skala likert dengan rentang penilaian sebagai berikut:

Tabel 3.

Alternatif Jawaban Responden

\begin{tabular}{cccc}
\hline No. & Simbol & Alternatif Jawaban & Skor \\
\hline 1. & SS & Sangat Setuju & 5 \\
2. & S & Setuju & 4 \\
3. & N & Netral & 3 \\
4. & TS & Tidak Setuju & 2 \\
5. & STS & Sangat Tidak Setuju & 1 \\
\hline Sumber: & Sugiyono, 2016 &
\end{tabular}

Uji validitas bertujuan untuk memeriksa apakah kuisioner sebagai instrumen penelitian sudah tepat untuk mengukur indikator dalam penelitian. Pernyataan pernyataan dalam kuesioner dikatakan valid apabila koefisien korelasi $\geq 0,3$ (Sugiyono, 2016:142). Uji reliabilitas instrumen dilakukan untuk mengetahui konsistensi alat ukur yang digunakan. Suatu instrumen dapat dikatakan reliable apabila koefisien Alpha Cronbach $\geq 0,6$ (Sugiyono, $2016: 147$ ).

Teknik analisis data yang digunakan dalam penelitian ini adalah PLS (Partial Least Square). PLS (Partial Least Square) adalah analisis persamaan struktural (SEM) berbasis varian yang secara simultan dapat melakukan pengujian model pengukuran sekaligus pengujian model struktural. Data yang diperoleh selama pengumpulan data di lapangan dianalisis dengan menggunakan statistik deskriptif dan statistik inferensial. Statistik deskriptif berupa distribusi frekuensi 
digunakan untuk menyajikan frekuensi jawaban responden terhadap variabel penelitian, sedangkan statistik inferensial berupa PLS (Partial Least Square).

Deskripsi data penelitian menyajikan penilaian responden untuk setiap butir-butir pernyataan berkaitan dengan variabel penelitian. Untuk mendeskripsikan penilaian rata-rata responden mengenai variabel-variabel dalam penelitian, hasil jawaban responden disesuaikan dengan desain skala pengukuran yang telah ditetapkan kemudian diformulasikan ke dalam beberapa interval kelas (Suharsono, 2010:21). Rumus interval kelas adalah sebagai berikut:

$$
\begin{aligned}
& \text { Interval kelas }=\frac{\text { Nilai tertinggi }- \text { nilai terendah }}{\text { Jumlah kelas }} \\
& \text { Interval kelas }=\frac{5-1}{5}=0,8
\end{aligned}
$$

Berdasarkan nilai interval tersebut, maka distribusi jawaban responden memiliki rentang penilaian seperti pada Tabel 5. sebagai berikut

\section{Tabel 4.}

\begin{tabular}{ccc}
\multicolumn{3}{c}{ Rentang Penlilaian Jawaban Responden } \\
\hline No. & Rentang & Kriteria \\
\hline 1. & $1,00-1,80$ & Sangat tidak baik \\
2. & $1,81-2,60$ & Tidak baik \\
3. & $2,61-3,40$ & Cukup baik \\
4. & $3,41-4,20$ & Baik \\
5. & $4,21-5,00$ & Sangat baik \\
\hline \multicolumn{2}{l}{ Sumber : Suharsono, 2010}
\end{tabular}

\section{HASIL DAN PEMBAHASAN}

Karakteristik responden dalam penelitian ini dibagi menjadi empat karakter, yakni : berdasarkan usia, jenis kelamin, pendidikan dan perkerjaan yang berkaitan dengan penelitian yang dilakukan. Deskripsi mengenai karakteristik responden dapat dilihat pada Tabel 5. Sebagai berikut 
Tabel 5.

Karakteristik Responden

\begin{tabular}{cllcc}
\hline No. & Variabel & Keterangan & Jumlah & Persentase (\%) \\
\hline 1. & Usia & $17-21$ tahun & 51 & 42,50 \\
& & $22-26$ tahun & 50 & 41,60 \\
& & $27-31$ tahun & 9 & 7,50 \\
& 32-36 tahun & 5 & 4,16 \\
& & Diatas 36 tahun & 5 & 4,16 \\
2. Jenis Kelamin & Total & $\mathbf{1 2 0}$ & $\mathbf{1 0 0 , 0}$ \\
& & Pria & 94 & 77,90 \\
& Wanita & 26 & 22,10 \\
3. Jenjang Pendidikan & Total & $\mathbf{1 2 0}$ & $\mathbf{1 0 0 , 0}$ \\
& Terakhir & SMA & 87 & 72,10 \\
& & Perguruan Tinggi & 33 & 27,90 \\
4. & Pekerjaan & Total & $\mathbf{1 2 0}$ & $\mathbf{1 0 0 , 0}$ \\
& & Mahasiswa & 81 & 68,00 \\
& & Pegawai negeri & 17 & 13,90 \\
& & Pegawai swasta & 14 & 11,50 \\
& & Wiraswasta & 8 & 6,60 \\
& & Total & $\mathbf{1 2 0}$ & $\mathbf{1 0 0 , 0}$ \\
\hline
\end{tabular}

Sumber : data diolah, 2018

Berdasarkan Tabel 5, dapat diketahui data didominasi oleh responden yang berusia pada rentang 17- 21 tahun sebesar 42,5\%; pria sebesar 77,9\%; pendidikan minimal SMA sebesar 72,1\% dan pelajar/ mahasiswa mendominasi sebesar $68 \%$.

Tabel 6.

Hasil Uji Validitas dan Reliabilitas

\begin{tabular}{|c|c|c|c|c|}
\hline No. & Variabel & Indikator & $\begin{array}{l}\text { Koefisien } \\
\text { Korelasi }\end{array}$ & $\begin{array}{c}\text { Alpha } \\
\text { Cronbach }\end{array}$ \\
\hline \multirow[t]{3}{*}{1.} & Kualitas & Kemasan produk & 0,800 & 0,811 \\
\hline & Produk & Ketahanan produk & 0,860 & \\
\hline & & Kehandalan produk & 0,910 & \\
\hline \multirow[t]{3}{*}{2.} & Persepsi & Harga produk yang sesuai dengan kualitas & 0,770 & 0,699 \\
\hline & Harga & Harga yang ditawarkan terjangkau & 0,842 & \\
\hline & & Harga dapat bersaing dengan produk lain & 0,765 & \\
\hline \multirow[t]{3}{*}{3.} & Saluran & Kemudahan untuk memperoleh produk & 0,816 & 0,829 \\
\hline & Distribusi & Ketersediaan produk & 0,902 & \\
\hline & & Lokasi pembelian produk & 0,887 & \\
\hline \multirow[t]{3}{*}{4.} & Daya tarik & Ketetapan media prmosi yang digunakan & 0,879 & 0,874 \\
\hline & promosi & Iklan yang menarik & 0,918 & \\
\hline & & Pesan dalam iklan mudah dimengerti & 0,887 & \\
\hline \multirow[t]{3}{*}{5.} & Kepuasan & Senang menggunakan produk & 0,919 & 0,920 \\
\hline & pelanggan & Harapan yang terpenuhi & 0,933 & \\
\hline & & Merasa Puas & 0,935 & \\
\hline \multirow[t]{3}{*}{6.} & Niat & Melakukan pembelian kembali & 0,904 & 0,890 \\
\hline & Pembelian & Relationship dengan produk berlangsung lama & 0,904 & \\
\hline & Ulang & Tetap kembali membeli produk meski harga naik & 0,927 & \\
\hline
\end{tabular}


Hasil uji valitas pada Tabel 6 Menunjukkan seluruh indikator pada masing masing variabel memiliki nilai koefisien korelasi diatas 0,3. Hal ini menggambarkan bahwa indikator telah tepat digunakan dalam mengukur variabel. Pada hasil uji reliabilitas, koefisien alpha cronbach masing - masing variabel menunjukkan nilai diatas 0,6 sehingga selruh alat ukur dalam mengkuru variabel dapat dinyatakan konsisten.

Tabel 7.

Penilaian Responden terhadap Variabel Kualitas Produk

\begin{tabular}{clcccccccc}
\hline \multirow{2}{*}{ No } & \multirow{2}{*}{ Indikator } & \multicolumn{9}{c}{ Distribusi Jawaban (\%) } & Rata- & \multirow{2}{*}{ Ket } \\
\cline { 3 - 7 } & & 1 & 2 & 3 & 4 & 5 & Rata & \\
\hline 1 & Kemasan produk & 0 & 1,6 & 10,8 & 48,3 & 39,1 & 4,25 & Baik \\
2 & Ketahanan produk & 0 & 0,8 & 12,5 & 57,5 & 29,1 & 4,15 & Baik \\
3 & Kehandalan produk & & 0 & 2,5 & 10 & 57,5 & 30 & 4,15 & Baik \\
& & Rata - Rata & & & & & & 4,18 & Baik \\
\hline
\end{tabular}

Sumber : data diolah, 2018

Tabel 7 menunjukkan hasil penilaian responden terhadap variabel kualitas produk dengan nilai rata - rata sebesar 4,18 , berada di kategori penilaian 3.41 4.20 yang berarti secara rata - rata variabel kualitas produk sudah dinilai baik dimana indikator kemasan produk memiliki nilai rata - rata tertinggi yaitu 4,25, hal ini menunjukan responden sangat setuju dimana Oli Eni memiliki kemasan produk yang menarik.

Tabel 8.

Penilaian Responden terhadap Variabel Persepsi Harga

\begin{tabular}{ccccccccc}
\hline \multirow{2}{*}{ No } & \multirow{2}{*}{ Indikator } & \multicolumn{4}{c}{ Distribusi Jawaban (\%) } & Rata- & \multirow{2}{*}{ Ket } \\
\cline { 3 - 6 } & & 1 & 2 & 3 & 4 & 5 & Rata & \\
\hline 1 & Harga produk yang sesuai dengan kualitas & 0 & 0,8 & 14,1 & 50 & 35 & 4,19 & Baik \\
2 & Harga yang ditawarkan terjangkau & 0 & 2,5 & 15 & 55,8 & 26,6 & 4,07 & Baik \\
3 & Harga dapat bersaing dengan produk lain & 0 & 0,8 & 23,3 & 47,5 & 28,3 & 4,03 & Baik \\
\hline \multicolumn{2}{r}{ Rata - Rata } & & & & & 4,10 & Baik \\
\hline
\end{tabular}

Sumber : data diolah, 2018

Tabel 8 menunjukkan hasil penilaian responden terhadap variabel persepsi harga dengan nilai rata - rata sebesar 4,10 , berada di kategori penilaian 3.41 - 
4.20 yang berarti secara rata - rata variabel persepsi harga sudah dinilai baik dimana indikator harga produk yang sesuai dengan kualitas memiliki nilai rata rata tertinggi yaitu 4,19, hal ini menunjukan responden sangat setuju dimana harga Oli Eni yang ditawarkan sesuai dengan kualitas yang diberikan.

Tabel 9.

Penilaian Responden terhadap Variabel Saluran Distribusi

\begin{tabular}{lllllllll}
\hline \multirow{2}{*}{ No } & \multirow{2}{*}{ Indikator } & \multicolumn{3}{c}{ Distribusi Jawaban $(\%)$} & \multicolumn{3}{c}{ Rata- } & \multirow{2}{*}{ Ket } \\
\cline { 3 - 9 } & & 1 & 2 & 3 & 4 & 5 & Rata & \\
\hline 1 & Kemudahan untuk memperoleh produk & 0 & 2,5 & 21,6 & 59,1 & 16,6 & 3,90 & Baik \\
2 & Ketersedian produk & 0 & 3,3 & 20,8 & 63,3 & 12,5 & 3,85 & Baik \\
3 & Lokasi pembelian produk & 0,8 & 4,1 & 19,1 & 66,6 & 9,1 & 3,79 & Baik \\
Rata & Rata & & & & & & 3,85 & Baik \\
\hline
\end{tabular}

Sumber : data diolah, 2018

Tabel 9 menunjukkan hasil penilaian responden terhadap variabel saluran distribusi dengan nilai rata - rata sebesar 3,85, berada di kategori penilaian 3.41 4.20 yang berarti secara rata - rata variabel saluran distribusi sudah dinilai baik dimana indikator kemudahan untuk memperoleh produk memiliki nilai rata - rata tertinggi yaitu 3,90, hal ini menunjukan responden sangat setuju dimana produk oli sepeda motor merek Eni mudah diperoleh.

Tabel 10.

Penilaian Responden terhadap Variabel Daya Tarik Promosi

\begin{tabular}{|c|c|c|c|c|c|c|c|c|}
\hline \multirow{2}{*}{ No } & \multirow{2}{*}{ Indikator } & \multicolumn{5}{|c|}{ Distribusi Jawaban (\%) } & \multirow{2}{*}{$\begin{array}{l}\text { Rata- } \\
\text { Rata }\end{array}$} & \multirow{2}{*}{ Ket } \\
\hline & & 1 & 2 & 3 & 4 & 5 & & \\
\hline 1 & Ketepatan media promosi yang digunakan & 0,8 & 5,8 & 34,1 & 43,3 & 15,8 & 3,68 & Baik \\
\hline 2 & Iklan yang menarik & 0,8 & 7,5 & 41,6 & 40,8 & 9,1 & 3,50 & Baik \\
\hline 3 & Pesan dalam iklan mudah dimengerti & 0,8 & 7,5 & 41,6 & 41,6 & 8,3 & 3,49 & Baik \\
\hline \multicolumn{2}{|c|}{ Rata - Rata } & & & & & & 3,56 & Baik \\
\hline
\end{tabular}

Tabel 10 menunjukkan hasil penilaian responden terhadap variabel daya tarik promosi dengan nilai rata - rata sebesar 3,56, berada di kategori penilaian 3.41 - 4.20 yang berarti secara rata - rata variabel daya tarik promosi sudah dinilai baik dimana indikator ketepatan media promosi yang digunakan memiliki 
nilai rata - rata tertinggi yaitu 3,68 , hal ini menunjukan responden sangat setuju dimana media promosi yang digunakan oli sepeda motor merek Eni sudah tepat.

Tabel 11.

Penilaian Responden terhadap Variabel Kepuasan Pelanggan

\begin{tabular}{|c|c|c|c|c|c|c|c|c|}
\hline \multirow{2}{*}{ No } & \multirow{2}{*}{ Indikator } & \multicolumn{5}{|c|}{ Distribusi Jawaban (\%) } & \multirow{2}{*}{$\begin{array}{l}\text { Rata- } \\
\text { Rata }\end{array}$} & \multirow{2}{*}{ Ket } \\
\hline & & 1 & 2 & 3 & 4 & 5 & & \\
\hline 1 & Senang menggunakan produk & 0,8 & 1,6 & 15,8 & 53,3 & 28,3 & 4,07 & Baik \\
\hline 2 & Harapan yang terpenuhi & 0,8 & 3,3 & 15,8 & 54,1 & 25,8 & 4,01 & Baik \\
\hline 3 & Merasa puas & 0 & 5 & 15,8 & 52,5 & 26,6 & 4,01 & Baik \\
\hline \multicolumn{2}{|c|}{ Rata - Rata } & & & & & & 4,03 & Baik \\
\hline
\end{tabular}

Tabel 11 menunjukkan hasil penilaian responden terhadap variabel kepuasan pelanggan dengan nilai rata - rata sebesar 4,03, berada di kategori penilaian $3.41-4.20$ yang berarti secara rata - rata variabel kepuasan pelanggan sudah dinilai baik dimana indikator senang menggunakan produk memiliki nilai rata - rata tertinggi yaitu 4,07 , hal ini menunjukan responden sangat setuju dimana responden senang menggunakan Oli Eni.

Tabel 12.

Penilaian Responden terhadap Variabel Niat Pembelian Ulang

\begin{tabular}{|c|c|c|c|c|c|c|c|c|}
\hline \multirow{2}{*}{ No } & \multirow{2}{*}{ Indikator } & \multicolumn{5}{|c|}{ Distribusi Jawaban (\%) } & \multirow{2}{*}{$\begin{array}{l}\text { Rata- } \\
\text { Rata }\end{array}$} & \multirow{2}{*}{ Ket } \\
\hline & & 1 & 2 & 3 & 4 & 5 & & \\
\hline 1 & Melakukan pembelian kembali & 0 & 1,6 & 21,6 & 54,1 & 22,5 & 3,98 & Baik \\
\hline 2 & Relationship dengan produk berlangsung lama & 0 & 5 & 17,5 & 60,8 & 16,6 & 3,89 & Baik \\
\hline 3 & Tetap kembali membeli produk meski harga naik & 0,8 & 10 & 31,6 & 45,8 & 11,6 & 3.58 & Baik \\
\hline \multicolumn{7}{|c|}{ Rata - Rata } & 3,81 & Baik \\
\hline
\end{tabular}

Tabel 12 menunjukkan hasil penilaian responden terhadap variabel niat pembelian ulang dengan nilai rata - rata sebesar 3,81, berada di kategori baik dimana indikator melakukan pembelian kembali memiliki nilai rata - rata tertinggi yaitu 3,98, hal ini menunjukan responden sangat setuju dimana responden akan kembali menggunakan Oli Eni. 
Tabel 13.

Outer Loadings

\begin{tabular}{ccccccc}
\hline & $\begin{array}{c}\text { Daya tarik } \\
\text { Promosi }\end{array}$ & Kepuasan & $\begin{array}{c}\text { Kualitas } \\
\text { Produk }\end{array}$ & $\begin{array}{c}\text { Niat beli } \\
\text { ulang }\end{array}$ & $\begin{array}{c}\text { Persepsi } \\
\text { harga }\end{array}$ & $\begin{array}{c}\text { Saluran } \\
\text { distribusi }\end{array}$ \\
\hline X.1.1 & & & 0.774 & & & \\
X.1.2 & & & 0.914 & & & \\
X.1.3 & & & 0.854 & & 0.835 & \\
X.2.1 & & & & & 0.915 & \\
X.2.2 & & & & & 0.843 & \\
X.2.3 & & & & & & 0.769 \\
X.3.1 & & & & & \\
X.3.2 & & & & & 0.919 \\
X.3.3 & & & & & \\
X.4.1 & 0.905 & & & & \\
X.4.2 & 0.928 & & & & \\
X.4.3 & 0.810 & & & & \\
Y1.11 & & 0.899 & & & \\
Y1.12 & & 0.930 & & & \\
Y1.13 & & 0.921 & & 0.904 & & \\
Y2.11 & & & & 0.910 & & \\
Y2.22 & & & & 0.763 & & \\
Y2.23 & & & & &
\end{tabular}

Tabel 13 memperlihatkan bahwa semua indikator memiliki loading factor di atas 0,50 . Hal ini dapat disimpulkan bahwa konstruk mempunyai convergent validity yang baik.

Tabel 14.

Cross Loadings

\begin{tabular}{lcccccc}
\hline & $\begin{array}{c}\text { Daya tarik } \\
\text { Promosi }\end{array}$ & Kepuasan & $\begin{array}{c}\text { Kualitas } \\
\text { Produk }\end{array}$ & $\begin{array}{c}\text { Niat beli } \\
\text { ulang }\end{array}$ & $\begin{array}{c}\text { Persepsi } \\
\text { harga }\end{array}$ & $\begin{array}{c}\text { Saluran } \\
\text { distribusi }\end{array}$ \\
\hline X.1.1 & 0.304 & 0.403 & $\mathbf{0 . 7 7 4}$ & 0.299 & 0.497 & 0.388 \\
X.1.2 & 0.243 & 0.538 & $\mathbf{0 . 9 1 4}$ & 0.367 & 0.514 & 0.456 \\
X.1.3 & 0.172 & 0.497 & $\mathbf{0 . 8 5 4}$ & 0.375 & 0.478 & 0.383 \\
X.2.1 & 0.310 & 0.467 & 0.501 & 0.393 & $\mathbf{0 . 8 3 5}$ & 0.351 \\
X.2.2 & 0.200 & 0.483 & 0.480 & 0.358 & $\mathbf{0 . 9 1 5}$ & 0.353 \\
X.2.3 & 0.153 & 0.412 & 0.534 & 0.299 & $\mathbf{0 . 8 4 3}$ & 0.333 \\
X.3.1 & 0.374 & 0.429 & 0.316 & 0.469 & 0.330 & $\mathbf{0 . 7 6 9}$ \\
X.3.2 & 0.313 & 0.568 & 0.433 & 0.473 & 0.347 & $\mathbf{0 . 9 1 9}$ \\
X.3.3 & 0.381 & 0.560 & 0.474 & 0.489 & 0.353 & $\mathbf{0 . 8 7 3}$ \\
X.4.1 & $\mathbf{0 . 9 0 5}$ & 0.484 & 0.303 & 0.567 & 0.251 & 0.380 \\
X.4.2 & $\mathbf{0 . 9 2 8}$ & 0.405 & 0.269 & 0.554 & 0.269 & 0.333 \\
X.4.3 & $\mathbf{0 . 8 1 0}$ & 0.307 & 0.122 & 0.492 & 0.142 & 0.385 \\
Y1.11 & 0.432 & $\mathbf{0 . 8 9 9}$ & 0.494 & 0.689 & 0.502 & 0.509 \\
Y1.12 & 0.458 & $\mathbf{0 . 9 3 0}$ & 0.552 & 0.739 & 0.453 & 0.588 \\
Y1.13 & 0.383 & $\mathbf{0 . 9 2 1}$ & 0.517 & 0.684 & 0.497 & 0.582 \\
Y2.11 & 0.608 & 0.700 & 0.396 & $\mathbf{0 . 9 0 4}$ & 0.320 & 0.502 \\
Y2.22 & 0.501 & 0.747 & 0.440 & $\mathbf{0 . 9 1 0}$ & 0.437 & 0.510 \\
Y2.23 & 0.472 & 0.511 & 0.181 & $\mathbf{0 . 7 6 3}$ & 0.279 & 0.414 \\
\hline
\end{tabular}

Sumber : data diolah, 2018 
Tabel 14. Diketahui bahwa nilai cross loading menunjukkan adanya discriminant validity yang baik. Hal tersebut dapat dilihat dari nilai loading factor lebih tinggi dibandingkan nilai korelasi indikator tersebut dengan konstruk lainnya.

Tabel 15.

Nilai AVE

\begin{tabular}{lcc}
\hline & AVE & Akar AVE \\
\hline Daya tarik Promosi & 0,779 & 0,883 \\
Kepuasan & 0,840 & 0,917 \\
Kualitas Produk & 0,721 & 0,849 \\
Niat beli ulang & 0,742 & 0,862 \\
Persepsi harga & 0,748 & 0,865 \\
Saluran distribusi & 0,733 & 0,856 \\
\hline Sumber : data diolah, 2018 &
\end{tabular}

Tabel 16.

Korelasi Antar Variabel Laten

\begin{tabular}{lcccccc}
\hline & $\begin{array}{c}\text { Daya tarik } \\
\text { Promosi }\end{array}$ & Kepuasan & $\begin{array}{c}\text { Kualitas } \\
\text { Produk }\end{array}$ & $\begin{array}{c}\text { Niat beli } \\
\text { ulang }\end{array}$ & $\begin{array}{c}\text { Persepsi } \\
\text { harga }\end{array}$ & $\begin{array}{c}\text { Saluran } \\
\text { distribusi }\end{array}$ \\
\hline Daya tarik Promosi & 1.000 & & & & & \\
Kepuasan & 0.464 & 1.000 & & & & \\
Kualitas Produk & 0.276 & 0.569 & 1.000 & & & \\
Niat beli ulang & 0.612 & 0.769 & 0.411 & 1.000 & & \\
Persepsi harga & 0.258 & 0.527 & 0.582 & 0.407 & 1.000 & \\
Saluran distribusi & 0.411 & 0.612 & 0.482 & 0.555 & 0.400 & 1.000 \\
\hline Sumber $:$ data diolah, 2018 & & & & &
\end{tabular}

Sumber : data diolah, 2018

Tabel 15 menunjukan bahwa akar AVE terendah adalah 0,849. Nilai korelasi antar konstruk terbesar pada Tabel 16 adalah 0,769. Dengan demikian semua nilai akar AVE jauh lebih besar daripada nilai korelasi antar konstruk sehingga dapat dikatakan bahwa data sudah reliabel.

Tabel 17.

Nilai $R$-Squares

\begin{tabular}{lc}
\hline & R Square \\
\hline Daya tarik Promosi & \\
Kepuasan & 0,540 \\
Kualitas Produk & \\
Niat beli ulang & 0,591 \\
Persepsi harga & \\
Saluran distribusi & \\
Sumber : data diolah, 2018 &
\end{tabular}


Nilai $R$-square variabel Kepuasan sebesar 0,540 pada Tabel 17 dapat diintepretasikan bahwa 54\% variabilitas konstruk kepuasan dijelaskan oleh variabel, kualitas produk, persepsi harga, saluran distribusi dan daya tarik promosi sedangkan $46 \%$ variabel kepuasan dijelaskan oleh variabel di luar model. Demikian juga nilai $\mathrm{R}$ Square variabel niat beli ulang sebesar 0,591 yang menunjukkan bahwa 59,10\% variabilitas niat beli ulang dijelaskan oleh variabel kepuasan sedangkan sisanya 40,90\% dijelaskan oleh variabel di luar model.

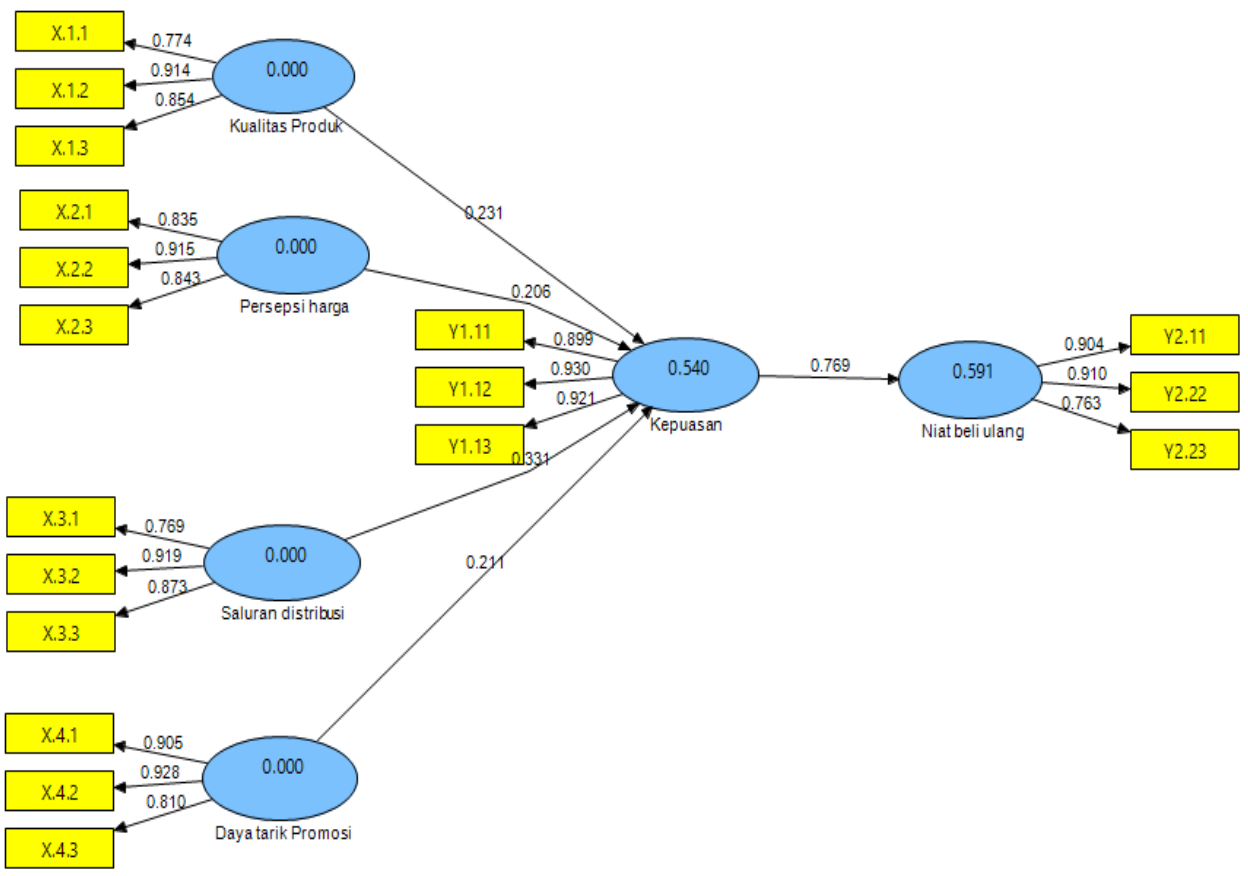

\section{Gambar 2. diagram Jalur Model Analisis}

Model struktural tersebut disebut model refleksif dimana covariance pengukuran indikator dipengaruhi oleh konstruk laten atau mencerminkan variasi dari konstruk unidimensional yang digambarkan dengan bentuk elips dengan beberapa anak panah dari konstruk ke indikator. Model ini menghipotesiskan 
bahwa perubahan pada konstruk laten akan mempengaruhi perubahan pada indikator.

Signifikansi parameter yang diestimasi memberikan informasi yang sangat berguna mengenai hubungan antara variabel-variabel penelitian. Dasar yang digunakan dalam menguji hipotesis adalah nilai yang terdapat pada output path coefficients. Tabel 18 memberikan output estimasi untuk pengujian model struktural.

Tabel 18.

Path Coefficients (Mean, STDEV, T-Values)

\begin{tabular}{lccccc}
\hline & $\begin{array}{c}\text { Original } \\
\text { Sample } \\
(\mathbf{O})\end{array}$ & $\begin{array}{c}\text { Sample } \\
\text { Mean } \\
(\mathbf{M})\end{array}$ & $\begin{array}{c}\text { Standard } \\
\text { Deviation } \\
\text { (STDEV) }\end{array}$ & $\begin{array}{c}\text { Standard } \\
\text { Error } \\
(\text { STERR) }\end{array}$ & $\begin{array}{c}\text { T Statistics } \\
(\mid \mathbf{O} \text { STERR })\end{array}$ \\
\hline Daya tarik Promosi -> Kepuasan & 0,211 & 0,214 & 0,083 & 0.083 & 2,537 \\
Kepuasan -> Niat beli ulang & 0,769 & 0,771 & 0,046 & 0,046 & 16,693 \\
Kualitas Produk -> Kepuasan & 0,231 & 0,237 & 0,086 & 0,086 & 2,677 \\
Persepsi harga -> Kepuasan & 0,206 & 0,195 & 0,093 & 0,093 & 2,207 \\
Saluran distribusi -> Kepuasan & 0,331 & 0,335 & 0,097 & 0,097 & 3,402 \\
\hline
\end{tabular}

Sumber : data diolah, 2018

Pengujian terhadap hipotesis dalam metode PLS dilakukan dengan menggunakan simulasi terhadap setiap hubungan yang dihipotesiskan, dalam hal ini dilakukan metode bootstrap terhadap sampel. Metode bootstrap juga berfungsi untuk meminimalkan masalah ketidaknormalan data penelitian yang digunakan. Pada penelitian ini telah ditentukan sebelumnya nilai T-tabel dengan signifikansi $5 \%$ atau 0,05. Semua koefisien jalur pada Tabel 18 memiliki nilai T Statistic di atas 1,96 sehingga dinyatakan memiliki pengaruh yang signifikan. Pengujian masing-masing hipotesis dibahas pada sub berikut ini

Hasil pengujian hipotesis pertama menunjukkan bahwa koefisien jalur pengaruh Kualitas Produk terhadap Kepuasan Pelanggan adalah sebesar 0,231 dengan nilai t-statistik sebesar 2,677. Nilai t-statistik tersebut lebih besar dari 1,96 
yang menunjukkan bahwa ada pengaruh yang signifikan antara variabel Kualitas Produk terhadap Kepuasan Pelanggan. Koefisen jalurnya yang bernilai positif menunjukkan bahwa Kualitas Produk berpengaruh positif terhadap Kepuasan Pelanggan. Semakin baik Kualitas Produk maka Kepuasan Pelanggan semakin baik. Hal ini berarti Hipotesis 1 diterima.

Hasil rangkuman penilaian responden yang disajikan dalam deskripsi variabel penelitian menunjukkan bahwa penilaian responden terhadap kualitas produk berada dalam kategori sangat baik sehingga menghasilkan tingkat kepuasan berada dalam kategori sangat baik. Responden merasa puas dengan keistimewaan yang dimiliki produk berupa ketahanan dan kemasan yang menarik dari produk sepeda motor merek Eni. Strategi Eni dalam menjadikan ketahanan oli mesin dan desain yang menarik sebagai keunggulan kompetitifnya berhasil meningkatkan kepuasan pelanggan terhadap produknya. Hasil penelitian ini mendukung temuan sejumlah penelitian terhadaulu seperti Alelign (2014), Ehsani (2014), Atiyah (2016), Dharmayoga (2017) dan Dudin (2017) yang menunjukan bahwa kualitas produk berpengaruh positif signifikan terhadap kepuasan pelanggan.

Hasil pengujian hipotesis kedua menunjukkan bahwa koefisien jalur pengaruh Persepsi Harga terhadap Kepuasan Pelanggan adalah sebesar 0,206 dengan nilai t-statistik sebesar 2,207. Nilai t-statistik tersebut lebih besar dari 1,96 yang menunjukkan bahwa ada pengaruh yang signifikan antara variabel Persepsi Harga terhadap Kepuasan Pelanggan. Koefisen jalurnya yang bernilai positif menunjukkan bahwa Persepsi Harga berpengaruh positif terhadap Kepuasan 
Pelanggan. Semakin baik Persepsi Harga maka Kepuasan Pelanggan semakin baik. Hal ini berarti Hipotesis 2 diterima.

Hasil rangkuman penilaian responden yang disajikan dalam deskripsi variabel penelitian menunjukkan bahwa penilaian responden terhadap persepsi harga berada dalam kategori sangat baik sehingga menghasilkan tingkat kepuasan berada dalam kategori sangat baik. Responden merasa puas dengan harga yang ditawarkan sesuai dengan kualitas yang diberikan produk sepeda motor merek Eni. Strategi Eni dalam menawarkan produk dengan harga yang terjangkau dan kualitas yang sesuai berhasil meningkatkan kepuasan pelanggan terhadap produknya. Hasil penelitian ini mendukung temuan sejumlah penelitian terhadaulu seperti Sukanto (2015), Ehsani (2014) dan Mohammad (2015) yang menunjukan bahwa persepsi harga berpengaruh positif signifikan terhadap kepuasan pelanggan.

Hasil pengujian hipotesis ketiga menunjukkan bahwa koefisien jalur pengaruh Saluran Distribusi terhadap Kepuasan Pelanggan adalah sebesar 0,331dengan nilai t-statistik sebesar 3,402. Nilai t-statistik tersebut lebih besar dari 1,96 yang menunjukkan bahwa ada pengaruh yang signifikan antara variabel Saluran Distribusi terhadap Kepuasan Pelanggan. Koefisen jalurnya yang bernilai positif menunjukkan bahwa Saluran Distribusi berpengaruh positif terhadap Kepuasan Pelanggan. Semakin baik Saluran Distribusi maka Kepuasan Pelanggan semakin baik. Hal ini berarti Hipotesis 3 diterima.

Hasil rangkuman penilaian responden yang disajikan dalam deskripsi variabel penelitian menunjukkan bahwa penilaian responden terhadap saluran 
distirbusi berada dalam kategori sangat baik sehingga menghasilkan tingkat kepuasan berada dalam kategori sangat baik. Responden merasa puas dengan produk sepeda motor merek Eni karena selalu tersedia dan mudah untuk ditemukan. Strategi Eni dalam mendistribusikan produknya dengan baik berhasil meningkatkan kepuasan pelanggan terhadap produknya. Hasil penelitian ini mendukung temuan sejumlah penelitian terhadaulu seperti Sukanto (2015), Amilia (2016) dan Rao (2014) yang menunjukan bahwa saluran distribusi berpengaruh positif signifikan terhadap kepuasan pelanggan.

Hasil pengujian hipotesis keempat menunjukkan bahwa koefisien jalur pengaruh Daya Tarik Promosi terhadap Kepuasan Pelanggan adalah sebesar 0,211 dengan nilai t-statistik sebesar 2,537. Nilai t-statistik tersebut lebih besar dari 1,96 yang menunjukkan bahwa ada pengaruh yang signifikan antara variabel Daya Tarik Promosi terhadap Kepuasan Pelanggan. Koefisen jalurnya yang bernilai positif menunjukkan bahwa Daya Tarik Promosi berpengaruh positif terhadap Kepuasan Pelanggan. Semakin baik Daya Tarik Promosi maka Kepuasan Pelanggan semakin baik. Hal ini berarti Hipotesis 4 diterima.

Hasil rangkuman penilaian responden yang disajikan dalam deskripsi variabel penelitian menunjukkan bahwa penilaian responden terhadap daya tarik promosi berada dalam kategori sangat baik sehingga menghasilkan tingkat kepuasan berada dalam kategori sangat baik. Responden merasa puas dengan produk sepeda motor merek Eni karena menawarkan promosi yang menarik. Strategi Eni dalam melakukan pengiklanan dan promosi yang menarik berhasil meningkatkan kepuasan pelanggan terhadap produknya. Hasil penelitian ini 
mendukung temuan sejumlah penelitian terhadaulu seperti Sukanto (2015), Faradina (2016), Dharmayoga (2017) dan Ginantra (2017) yang menunjukan bahwa daya tarik promosi berpengaruh positif signifikan terhadap kepuasan pelanggan.

Hasil pengujian hipotesis kelima menunjukkan bahwa koefisien jalur pengaruh Kepuasan Pelanggan terhadap Niat Pembelian Ulang adalah sebesar 0,769 dengan nilai t-statistik sebesar 16,693. Nilai t-statistik tersebut lebih besar dari 1,96 yang menunjukkan bahwa ada pengaruh yang signifikan antara variabel Kepuasan Pelanggan terhadap Niat Pembelian Ulang. Koefisen jalurnya yang bernilai positif menunjukkan bahwa Kepuasan Pelanggan berpengaruh positif terhadap Niat Pembelian Ulang. Semakin baik Kepuasan Pelanggan maka Niat Pembelian Ulang semakin baik. Hal ini berarti Hipotesis 5 diterima.

Pengujian hipotesis terhadap hubungan kedua variabel ini menunjukkan hasil yang diterima, yaitu kepuasan pelanggan berpengaruh positif dan signifikan terhadap niat pembelian ulang. Itu berarti, semakin baik kepuasan yang dirasakan pelanggan produk sepeda motor merek Eni, maka akan semakin tinggi pula niat pembelian ulang terhadap produk tersebut.

Hasil rangkuman penilaian responden yang disajikan dalam deskripsi variabel penelitian menunjukkan bahwa kepuasan pelanggan berada dalam kategori sangat baik sehingga menghasilkan tingkat niat pembelian ulang berada dalam kategori sangat baik. Responden akan ingin membeli kembali karena merasa puas dengan produk sepeda motor merek Eni. Kualitas produk, persepsi harga, saluran distribusi dan daya tarik promosi oli sepeda motor merek Eni 
mampu meningkatkan kepuasan pelanggan. Kepuasan ini berdampak secara positif dan signifikan terhadap niat pembelian ulang produk sepeda motor merek Eni. Strategi Eni dalam meningkatkan kepuasan pelanggannya dengan menghadirkan kualitas produk yang baik, persepsi harga yang baik saluran distribusi yang baik dan promosi yang menarik mampu menciptakan niat pembelian ulang.

\section{SIMPULAN DAN SARAN}

Berdasarkan pembahasan yang telah dipaparkan, maka dapat diambil kesimpulan dari penelitian sebagai berikut: Kualitas produk berpengaruh positif dan signifikan terhadap kepuasan pelanggan, sehingga semakin baik kualitas yang dimiliki produk oli sepeda motor merek Eni maka akan semakin tinggi pula kepuasan pelanggan. Persepsi harga berpengaruh positif dan signifikan terhadap kepuasan pelanggan, sehingga semakin baik persepsi harga produk oli sepeda motor merek Eni yang terbentuk dibenak konsumen, maka akan semakin tinggi pula kepuasan pelanggan. Saluran distribusi berpengaruh positif dan signifikan terhaap kepuasan pelanggan, sehingga semakin baik saluran distribusi yang dimiliki oli sepeda motor merek Eni, maka akan semakin tinggi pula kepuasan pelanggan. Daya tarik promosi berpengaruh positif dan signifikan terhaap kepuasan pelanggan, sehingga semakin baik daya promosi yang dimiliki oli sepeda motor merek Eni, maka akan semakin tinggi pula kepuasan pelanggan. Kepuasan pelanggan berpengaruh positif dan signifikan terhadap niat pembelian ulang, sehingga semakin tinggi kepuasan terhadap produk oli sepeda motor merek 
Eni maka akan semakin tinggi pula niat pembelian ulang. Saluran distribusi yang dimiliki produk oli sepeda motor merek Eni merupakan variabel yang paling mempengaruhi tingkat kepuasan pelanggan. Saluran distribusi yang baik membuat produk Oli Eni selalu tersedia di bengkel-bengkel sepeda motor di Denpasar, hal ini merupakan faktor yang paling mempengaruhi kepuasan pelanggan.

Berdasarkan hasil kesimpulan yang telah dipaparkan, maka saran yang dapat diberikan, diantaranya : Bagi perusahaan, hasil penelitian ini menunjukkan bahwa kualitas produk, persepsi harga, saluran distribusi dan daya tarik promosi berpengaruh positif dan signifikan terhadap kepuasan pelanggan. Saluran distribusi sebagai variabel yang paling mempengaruhi kepuasan pelanggan. Menjaga produk agar selalu tersedia menjadi faktor yang paling besar mempengaruhi kepuasaan pelanggan hal ini harus dipertahankan oleh perusahaan Eni dan faktor lainnya yaitu mudah memperoleh produk dan lokasi penjualan yang strategis harus lebih dimaksimalkan agar dapat lebih meningkatkan kepuasaan pelanggan produk oli sepeda motor merek Eni. Pelanggan yang merasa puas terhadap suatu produk akan menciptakan niat pembelian ulang. Perusahaan dapat menciptakan niat pembelian ulang terhadap produknya melalui peningkatan kepuasan pelanggan. Bagi penelitian selanjutnya, diharapkan dapat melibatkan responden yang lebih banyak sehingga hasil yang didapat lebih akurat, melakukan analisis mediasi dan menguji hubungan langsung kualitas produk, persepsi harga, saluran distribusi, daya tarik promosi terhadap niat beli ulang sehingga dapat diketahui apakah terdapat hubungan langsung atau tidak. 


\section{REFERENSI}

Abdullah, Thamrin dan Francis Tantri. 2012. Manajemen Pemasaran. Depok : PT Raja Grafindo Persada

Abdillah, W. dan Jogiyanto, H. M.,2009.Konsep Dan Aplikasi PLS (Partial Least Square) Untuk Penelitian Empiris. Badan Penerbit Fakultas Ekonomi Dan Bisnis UGM, Yogyakarta.

Ahmed, Selim and Md. Habibur Rahman. 2015. The Effects of Marketing Mix on Consumer Satisfaction: A Literature Review From Islamic Perspectives. Turkish Journal of Islamic Economics, Vol. 2, No, pp. 17-30

Alma, Buchari. 2007, Manajemen Pemasaran dan Pemasaran Jasa. Bandung: CV. Alfabeta.

Alelign, Dereje, Dr.B.V.Prasada Rao, Wako. Geda obse. 2014. The Impact of Marketing Mix on Customer Satisfaction. International Journal of Academic Research, 2(1), pp. 50 - 78

Amilia, Suri, Ayu Novianti. 2016. Pengaruh Bauran Pemasaran terhadap Kepuasan Konsumen pada Warung Kanasha di Kota Langsa. Jurnal Manajemen dan Keuangan, 5(1), hal. 1-10

Anjungroso, Fajar. 2017. Pelumas Eni Oil Terjual 1,5 Juta Liter. www.tribunnews.com. Diakses 26 September 2017.

Ardhanari, Margaretha. 2008. Customer Satisfaction Pengaruhnya terhadap Brand Preference dan Repurchase Intention Private Brand. Jurnal Riset Ekonomi dan Bisnis, 8(2), hal 1-18

Atiyah, Latif. 2016. Product's Quality and its Impact on Customer Satisfaction a Field Study in Diwaniyah Dairy Factory. Proceedings of the $10^{\text {th }}$ International Management Conference.

BPS. 2014. denpasarkota.bps.go.id. Diakses 28 Januari 2018

Dudin, Mihail N. 2017. Evaluating the Impact of Promotion Price, Product Quality, Service Quality, Customer Satisfaction and Repeating Purschase Incentives (Case Study: Amirah Chain Stores). Journal of Internet Banking and Commerce, June 2017, 22(8), pp.256-287

Ehsani, Zahra and Mohammad Hossein Ehsani. 2014. Effect of quality and price on customer satisfaction and commitment in Iran auto industry. International Journal of Service Science, Management and Engineering. 1(5), hal. 52-56 . 
Engkos, Ridwan Achmad Kuncoro. 2013. Cara Menggunakan dan Memaknai Path Analysis, Alfabeta: Bandung

Faradina, Anissa. 2016. Pengaruh Promosi dan Kualitas Pelayanan Terhadap Kepuasan Pelanggan pada Rumah Cantik Alamanda. Jurnal Ilmu dan Riset Manajemen, 5(7), hal. 1-25

Ghozali, Imam. 2008. Structural equation modeling: Metode alternatif dengan Partial Least Square. BP Universitas Diponegoro

Ginantra, Komang Gede, Ni Putu Nina Eka Lestari, AAN. Eddy Supriyadinata Gorda, Gede Sri Darma. 2017. Effects of Promotion, Product Quality, Brand Image and Price on Customer Satisfaction and Brand Switching Decision (A Case Study on Xl Cellular Card Users in Denpasar City, Bali, Indonesia). International Journal of Management and Economics Invention, Volume 3 Issue 12 Pages-1514-1523

Griffin, Jill. 2003. Customer Loyalty : Menumbuhkan Dan Mempertahankan Pelanggan. Jakarta, Airlangga

Gultom, Tonny Sopan Sofian, Hariyani, H.Zakaria Ismail. 2014. Pengaruh Merek, Saluran Distribusi terhadap Kepuasan Pelanggan, Loyalitas Pembelian Produk Aqua (Studi Kasus Pada PT. Bintang Suryasindo Cabang Pangkalpinang Bangka). Jurnal Ilmiah Progresif Manajemen Bisnis (JIPMB), 1(1), hal. 13-25

Hartati, Euis Rita. 2016. Eni Oil Naikan Pangsa Pasar Pelumas di Indonesia. www.beritasatu.com. Diakses 3 Maret 2018.

Umar, Husein. 2005. Riset pemasaran dan Perilaku Konsumen, Jakarta: PT Gramedia Pustaka Utama.

Ibzan, Eliasaph Farida Balarabe, Balarabe Jakada. 2016. Consumer Satisfaction and Repurchase Intentions. Developing Country Studies, 6(2), hal:1-10

Iman, Mustafa. 2016. Upaya Eni Oil Perluas Pasar di Nusantara. beritagar.id. Diakses 3 maret 2018.

Jahanshahi, Asghar Afshar, Mohammad Ali Hajizadeh Gashti, Seyed Abbas Mirdamadi, Khaled Nawaser and Seyed Mohammad Sadeq Khaksar. 2011. Study the Effects of Customer Service and Product Quality on Customer Satisfaction and Loyalty. International Journal of Humanities and Social Science, 1(7), pp. 1-18 
Andy Tejantara, Pengaruh Bauran Pemasaran terhadap...

Koesworodjati, Yudhi. 2006. Prinsip dasar Manajemen Pemasaran, FE-UNPAS. Bandung

Kotler, Philip dan Kevin Lane Keller. 2012. Marketing Management 13. New Jersey: Pearson Prentice Hall, Inc.

Kotler, Philip dan Gary Armstrong. 2014. Principle Of Marketing. $15^{\text {th }}$ edittion. New Jersey: Pearson Prentice Hall

Kusuma, Dharmayoga. 2017. Peran Customer Satisfaction Memediasi Pengaruh Marketing Mix Terhadap repurchase Intention. E-Jurnal Manajemen Unud, 6(3), pp. 1398-1424

Lupiyoadi, Rambat, (2013): Manajemen Pemasaran Jasa. Jakarta:Salemba Empat.

Mevita, Afrida Shela, Heru Suprihhadi. 2013. Pengaruh Bauran Pemasaran Terhadap Kepuasan Konsumen. Jurnal Ilmu \& Riset Manajemen, 2(9),hal. $1-10$

Moghadam, Javad Taheri, Hojjat Vahdati, Najmeddin Mousavi dan. 2014. A Study on the Effect of Marketing Mix on the Repurchase Intention with the Consideration of the Mediating Role of Brand Equity (Case Study: Ghaem Shahr Refah Bank). Adv. Environ. Biol., 8(21), pp: 467-474.

Mohammad, Haruna Isa. 2015. 7ps marketing mix and retail bank customer satisfaction in Northeast Nigeria. British Journal of Marketing Studies, 3(3), pp: 71-88.

Nugraheni, Rini dan Comaeni Enril Ferdinan. 2013. Analisis Pengaruh Persepsi Harga, Persepsi Kualitas Produk dan Promosi Terhadap Keputusan Pembellian Sepeda Motor Suzuki (Studi Pada Pembeli - Penguna Sepeda Motor Suzuki di Kota Solo). Diponegoro Journal of Management, 2(2), hal. 1-8.

Oktavita, Riska, suharyono dan Kadarisman Hidayat.2013. Pengaruh bauran pemasaran terhadap keputusan pembelian (survai pada mahasiswa yang mengkonsumsi teh botol sosro jurusan ilmu administrasi bisnis angkatan 2012/2013 fakultas ilmu administrasi universitas brawijaya malang). Jurnal administrasi bisnis, 3(2), pp: 1-8.

Palma, Marisa Arnindita dan Anik Lestari Andjarwati. 2016. Pengaruh Kualitas Produk, Kemudahan dan Harga terhadap Niat pembelian Ulang dengan Kepuasan Sebagai Variabel Intervening. Journal of Research in Economic and Management. 16(1), hal. 84-104. 
Prastiwi, Septi Kurnia. 2012. Analisis anteseden loyalitas dan wom serta pengaruh nya terhadap Repurchase Intention pada produk susu sgm (studi pada orang tua siswa teman sejati sari husada Yogyakarta). Riset manajemen \& akuntansi, 3(6), pp: 57-88.

Riduwan dan Kuncoro, Engkos Achmad. 2011. Cara Menggunakan dan Memaknai Analisis Jalur ( Path Analysis ). Bandung : Alfabeta.

Ryu, K., Lee, Hye-Rin, andKim, W.G. 2012. The Influence of the Quality of the Physical Environment, Food, and Service on Restaurant Image, Customer Perceived Value, Customer Satisfaction, and Behavioral Intentions. International Journal of Contemporary Hospitality Management, Vol. 24, No.2, pp: 200-223.

Sudjana. 2005. Metode Statistika, Edisi Ke enam. Bandung : Tarsito

Sugiyono. 2016. Metode Penelitian Administratif Dilengkapi Dengan Metode $R \& D$. Bandung : Alfabeta.

Sukamto, Raymond dan Daniel B. Lumintan. 2015. The impact of marketing mix towards customer loyalty mediated by customer satisfaction of Blackberry Indonesia, iBuss Management, 3(2), pp: 316-324.

Suharsono.2010. Statistik Dalam Kajian Deskriptif, Inferensi, dan. Nonparametrik. Jakarta: Kencana Perpajakan: Teori \& Kasus Buku Satu. Jakarta.

Suryani, Tatik. 2008. Perilaku Konsumen; Implikasi Pada Strategi Pemasaran. Yogyakarta : Graha Ilmu.

Suyono, Sri Sukmawati, Pramono. 2012. Pertimbangan dalam Membeli Produk Barang atau Jasa. Intidayu Press. Jakarta

Tjiptono, Fandy. 2015. Strategi Pemasaran. Edisi Keempat. C,V ANDI OFFSET, Yogyakarta.

Tjiptono, Fandy dan Gregorisu Chandra, 2012, Pemasaran strategik. Yogyakarta, ANDI.

Toncar, M.F., Alon, I., andMisati, E. 2010. The Importance of Meeting Price Expectations: Linking Price to Service Quality. Journal of Product and Brand Management, Vol. 19, No. 4, pp: 295-305.

Varga, Anja, Jasmina Dlacic dan Maja Vujicic. 2014. Repurchasing Intentions in a Retail Store-Exploring The Impact of Colours. Ekonomski Vjesnik, 27(2), pp: 229-244. 
Andy Tejantara, Pengaruh Bauran Pemasaran terhadap...

Veva, Dwi Geno. 2015. Pengaruh Bauran Pemasaran Terhadap Kepuasan Konsumen pada Hotel Resty Menara Pekanbaru . JOM FISIP , 2(2), hal. $1-15$

Yulisetiarini, Diah, Ari Subagio, Hadi Paramu and Bambang Irawan. 2017. Customer Repurchase Intention and Satisfaction in Online Shopping. Internasional Business Management, 11(1), hal. 215-221. 